\title{
PENDAMPINGAN KELOMPOK KEWIRAUSAHAAN MUDA BAGI PEMULA BIDANG KELAUTAN DAN PERIKANAN DI POLITEKNIK KELAUTAN DAN PERIKANAN SORONG
}

\author{
Hendra Poltak ${ }^{1)}$, Gatot Hendra Prakoso ${ }^{2}$,Endang Gunaisah ${ }^{3)}$, Muhammad Ali Ulat ${ }^{3)}$, Mustasim ${ }^{3,4)}$, \\ Muhammad Zaki Latif ${ }^{1}$, Mohammad Sayuti ${ }^{3)}$, Misbah Sururi ${ }^{3)}$, Muhfizar ${ }^{4}$, Bambang Winarno ${ }^{5 \text { ) }}$ \\ 1)Teknik Budidaya Perikanan, Politeknik Kelautan dan Perikanan Sorong, Sorong, Papua Barat, Indonesia \\ ${ }^{2}$ )Manajemen, Universitas Binus, Jakarta, Jakarta, Indonesia \\ ${ }^{3}$ Teknik Penangkapan Ikan, Politeknik Kelautan dan Perikanan Sorong, Sorong, Papua Barat, Indonesia \\ 4)Mekanisasi Perikanan, Politeknik Kelautan dan Perikanan Sorong, Sorong, Papua Barat, Indonesia \\ ${ }^{5)}$ Pusat Pengembangan Wirausaha, Politeknik Kelautan dan Perikanan Sorong, Sorong, Papua Barat, Indonesia
}

Corresponding author : Hendra Poltak

E-mail : hendra.poltak@polikpsorong.ac.id

\section{Diterima 03 Februari 2021, Direvisi 07 Februari 2021, Disetujui 08 Februari 2021}

\begin{abstract}
ABSTRAK
Evaluasi yang dilakukan terhadap kegiatan wirausaha muda masih terdapat beberapa kelemahan kelompok seperti ide yang ditampilkan merupakan ide tahun sebelumnya, penyusunan proposal belum sesuai, belum ada strategi pemasaran, dan teknik presentasi yang kaku. Pengabdian masyarakat ini bertujuan untuk meningkatkan kemampuan berwirausaha sehingga dapat menjadi bekal Ketika lulus pendidikan. Metode pendampingan dilakukan dengan ceramah, diskusi, dan tanya jawab serta proses coaching kepada tiga kelompok wirausaha taruna dan satu wirausaha alumni. Hasil pendampingan dengan metode CPDT dan coaching meningkatnya kreativitas kelompok wirausaha, proposal bisnis sesuai pedoman, dan kelompok mampu melakukan presentasi lebih menarik dan efektif.
\end{abstract}

Kata kunci: wirausaha muda; pendampingan; ceramah; diskusi dan penugasan; coaching.

\begin{abstract}
The evaluation carried out on young entrepreneurial activities still has several weaknesses in the group, such as the ideas presented in the previous year, inadequate proposal preparation, no marketing strategy, and rigid presentation techniques. This community service aims to improve entrepreneurial skills so that they can become provisions when graduating from education. The mentoring method is carried out by lectures, discussions, and questions and answers as well as a coaching process to three youth entrepreneur groups and one alumni entrepreneur. The results of assistance with the CPDT method and coaching increased the creativity of entrepreneurial groups, business proposals according to guidelines, and groups were able to make more attractive and effective presentations.
\end{abstract}

Keywords: young entrepreneurs; accompaniment; lectures, discussions and assignments; coaching.

\section{PENDAHULUAN}

Semboyan "Jalasveva Jaya Mahe" bukanlah sekedar semboyan. Semboyan menunjukkan bahwa negara kita merupakan negara bahari yang memiliki potensi kelautan yang melimpah. Potensi dengan 11 sektor ekonomi kelautan diantaranya perikanan tangkap, perikanan budidaya, industri pengolahan hasil perikanan, industri bioteknologi kelautan, pertambangan dan energi, pariwisata bahari, hutan mangrove, perhubungan laut, sumber daya wilayah pulaupulau kecil, industri dan jasa maritim, dan sumber daya non konvensional yang mampu mensejahterakan bangsa Indonesia (dahuri, 2014).

Potensi kekayaan laut yang luar biasa ini ternyata belum dimanfaatkan secara optimal
(Lasabuda, 2013; Kadar, 2015; Sasvia, 2019). Pemanfaatan yang optimal tentunya sangat bermanfaat dalam menciptakan lapangan usaha, menyerap tenaga kerja, mengurangi kemiskinan, dan meningkatakan kesejahteraan. Banyak faktor yang menyebabkan tidak optimalnya pengelolaan sumber daya laut, satu diantaranya adalah sumber daya manusia.

Sumber daya manusia menjadi tolak ukur dalam pengembangan potensi laut. Sumber daya yang mampu, kompeten, dan cerdas menggunakan ilmu pengetahuan dan teknologi dalam mengolah laut, bahkan lebih dari itu dibutuhkan sumber daya yang bisa berinovasi memberikan nilai tambah sehingga sumber daya laut selain bernilai ekonomi tinggi, juga mampu menjaga keberlanjutan. 
Peran mengelola laut secara cerdas ini ada pada sosok wirausaha. Sosok yang mampu mengadopsi peluang usaha kelautan dan perikanan dari peran sebagai konsumen menjadi produsen atau dari pengguna menjadi pembuat dalam bentuk karya, ide, pemikiran yang kreatif dan inovatif. Sosok inilah yang mampu menciptakan lapangan usaha, menyerap tenaga kerja, mengurangi kemiskinan, dan meningkatkan kesejahteraan.

Perguruan Tinggi menjadi sarana bagi pembentukan wirausaha. Perguruan tinggi tidak hanya dituntut menciptakan tenaga terampil maupun ahli dalam bidangnya, namun juga membentuk insan-insan wirausaha yang mandiri dan mampu melalui kurikulum yang dikembangan sesuai dengan perkembangan zaman.

Penelitian (Suprapto, 2019) bahwa pembelajaran pembuatan proposal bisnis dapat membantu meningkatkan keterampilan kewirausahaan. Pengabdian masyarakat dengan mengundang pakar bisnis, pelaku UMKM melalui pelatihan, simulasi bisnis, magang, pendampingan intensif, Menyusun rencana bisnis menciptakan starup dan wirausaha mandiri (Budianto, Dianawati, and Iswahyudi, 2019). Pengembangan wirausaha melalui pendampingan dapat menciptakan mahasiswa wirausaha yang mampu bertahan dan sukses (Jaharuddin et al., 2019). Pendampingan wirausaha berbasis potensi dan partisipatif interaktif menumbuhkan semangat wirausaha mahasiswa(Suranto, Setiawan, and Sujalwo, 2018).

Selama 2 tahun menyelenggarakan kegiatan kewirausahaan banyak kegiatan yang harus di evaluasi. Hasil evaluasi terdapat beberapa hal yang menjadi area perbaikan diantaranya adalah kelompok wirausaha masih belum memahami proses penciptaan ide kreatif berbasis kelautan dan perikanan, penyusunan proposal bisnis dan prototype produk/jasa, pemasaran, penjualan, dan pelaporan. Berdasarkan hasil evaluasi tersebut maka dilakukan solusi berupa kegiatan pendampingan bagi kelompok wirausaha dengan tujuan untuk meningkatkan kemampuan dan keterampilan yang dapat dijadikan bekal untuk melakukan kegiatan wirausaha setelah lulus dari pendidikan.

\section{METODE}

Hasil yang optimal dapat dicapai secara efisien dan efektif dengan perencanaan yang baik (Ananda and Amiruddin, 2019). Hasil evaluasi digodok Kembali oleh Pusat Pengembangan Wirausaha bersama dengan Binus Incubator Coach, Binus University. Diskusi bersama untuk membuat perencanaan kegiatan dan metode yang digunakan dalam mencapai keberhasilan tujuan program yang sudah ditetapkan.

Hasil diskusi disepakati dilakukan pendampingan melalui metode ceramah plus diskusi dan tugas. Metode caramah, diskusi, plus dan tugas (CPDT) dapat mengaktifkan interaksi di kelas (Kusuma and Erlita, 2012), metode mengurut secara tertib dimulai dari Ceramah dilanjut dengan diskusi dan pemberian tugas. Metode coaching untuk meningkatkan potensi diri dalam mencapai target kinerja tertentu (Yuliawan, 2011). Metode menggali jawaban dari coachee atas pertanyaan-pertanyaan yang diajukan dan coachee menemukan jawaban untuk menjawab permasalahannya (Jerusalem, 2011). Peserta yang mengikuti coaching adalah tiga kelompok kewirausahaan yaitu kelompok krupuk tuna, aneka olahan mangrove dan kelompok oil spiner dan ditambah kelompok alumni yang mengajukan diri untuk mengikuti kegiatan. Coach berasal dari Universitas Binus dan didampingi oleh dosen Politeknik KP Sorong.

Diskusi juga membahas materi yang akan diberikan kepada klien. Kesepakatan diskusi adalah Klien akan diberikan materi sesuai dengan kebutuhan klien yaitu empat area yang kelemahannya akan diperbaiki. Area tersebut dapat dilihat pada tabel 1 ..

Tabel 1. Materi Pendampingan

\begin{tabular}{|c|c|c|}
\hline No & Materi & $\begin{array}{l}\text { Indikator } \\
\text { Keberhasilan }\end{array}$ \\
\hline 1 & $\begin{array}{l}\text { Proses penciptaan } \\
\text { ide kreatif }\end{array}$ & $\begin{array}{l}\text { Tersedianya } \\
\text { produk kreatif } \\
\text { taruna }\end{array}$ \\
\hline 2 & $\begin{array}{l}\text { Penyusunan } \\
\text { Proposal Bisnis dan } \\
\text { Prototype } \\
\text { Produk/Jasa }\end{array}$ & $\begin{array}{l}\text { Proposal } \\
\text { sesuai } \\
\text { dengan } \\
\text { pedoman }\end{array}$ \\
\hline 3 & $\begin{array}{ll}\text { Pemasaran dan } \\
\text { Penjualan }\end{array}$ & $\begin{array}{l}\text { Strategi } \\
\text { pemasaran } \\
\text { dan } \\
\text { penentuan } \\
\text { harga } \\
\end{array}$ \\
\hline 4 & $\begin{array}{l}\text { Presentasi Bisnis } \\
\text { dan Pelaporan }\end{array}$ & $\begin{array}{l}\text { tersedianya } \\
\text { pelaporan } \\
\text { standar }\end{array}$ \\
\hline
\end{tabular}

Optimalisasi hasil juga dilakukan dengan metode pendampingan melalui group Whatsappp. Coaching, dosen pendamping, dan anggota kelompok wirausaha berada di dalam group untuk berdiskusi.

\section{HASIL DAN PEMBAHASAN}

Pembukaan kegiatan pendampingan kelompok kewirausahaan dilakukan pada hari Kamis 30 Juli 2020. Hadir dalam kegiatan pembukaan Direktur Politeknik KP Sorong, 
para Pembantu Direktur, Ketua Program Studi, pembimbing kewirausahaan, Ketua Pusat Pengembangan Wirausaha, dan Binus Incubator Coach. Pembukaan diawali oleh laporan Pusat Pengembangan Wirausaha. Pada laporan disampaikan bahwa maksud dari kegiatan pendampingan adalah untuk meningkatkan potensi kelompok untuk dapat berwirausaha memberikan nilai tambah pada hasil sumber daya laut, terkhusus dalam waktu dekat kelompok akan disiapkan mengikuti festival kewirausahaan kelautan dan perikanan nasional di Jakarta. Direktur Politeknik KP Sorong selanjutnya membuka acara yang didahului memberikan arahan. Dalam arahannya, direktur menyampaikan peran Politeknik sebagai lembaga pendidikan vokasi untuk menciptakan wirausaha sesuai dengan Indikator Kinerja Utama yang menjadi target dari Unit Pelaksana teknis.

Selesai arahan dan pembukaan direktur dilanjutkan kepada pendampingan pertama. Pendampingan ini dimulai dengan perkenalan kelompok kewirausahaan kepada coach dan pendamping. Kelompok kewirausahaan menyampaikan perkembangan hasil kewirausahaan usai pelaksanaan kompetisi kewirausahaan tingkat kampus dan persiapan untuk mengikuti kompetisi kewirausahaan Kelautan dan Perikanan tingkat nasional.

Materi pertama ini adalah proses penciptaan ide kreatif. Pemberian materi ini dianggap penting oleh Pusat Pengembangan Wirausaha untuk diberikan karena kelompok wirausaha masih berkutat dengan dengan ide ide yang sifatnya di ulang dari tahun ke tahun tanpa adanya sentuhan inovasi. Materi ini diberikan dengan menggunakan metode ceramah, diskusi plus tugas. Gambar 1 pendampingan menggunakan metode ceramah, diskusi, dan tugas.

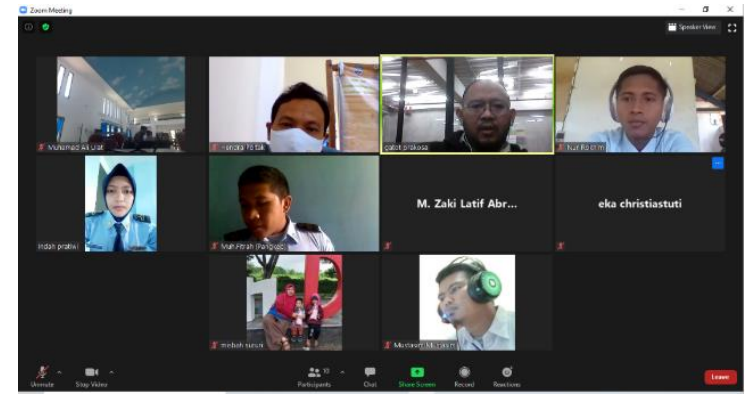

Gambar 1. Pendampingan dengan metode ceramah, diskusi, dan tugas

Pendamping memberikan gambaran kepada kelompok kewirausahaan taruna proses penciptaan ide kreatif dengan membawakan materi design thinking. Design thinking merupakan upaya mengidentifikasi kebutuhan manusia dengan menciptakan solusi melalui inovasi (Meinel and Von Thienen, 2016). Persoalan klasik bisnis adalah produk yang baru dibuat bisa cocok dengan selera pasar atau customer yang dituju, namun sering terjadi pasar menolak dan memilih untuk tetap bertahan pada produk yang lama. Akar permasalahan yang terjadi adalah :

1. Produk bisnis tidak sesuai dengan kebutuhan konsumen. Konsumen membutuhkan alat tapi yang kita berikan adalah servicenya, konsumen butuh pakaian tapi yang kita sediakan adalah accesoriesnya.

2. Sudah ada pemain lama yang sudah mapan dan besar, contoh sederhana kita tiba tiba disuatu suatu hari yang cerah punya ide untuk buat bisnis the teh kemasan, tapi kalau kita paksakan masuk ke pasar kemungkinan gagal karena sudah ada pemain di industri teh yang sudah mapan.

3. Calon (konsumen) tidak tahu tentang produk bisnis tersebut. Butuh waktu cukup lama untuk ojek online untuk mendapat tempat di masyarakat dan biaya yang dibutuhkan untuk mengedukasi masyarakat cukup besar, persoalannya bisnis pemula tidak mempunyai modal untuk melakukan ini.

Untuk dapat mempertemukan antara pebisnis dengan keinginan konsumen maka desaign thinking sangat penting disini. Pemateri memilih 6 langkah kecil dimulai dari empathize sampai kepada implement.

Empathize (berempati), bagi pelaku bisnis baru ini tidak mudah, biasanya pelaku bisnis baru sering kali merasa percaya diri bahwa produknya sangat bagus padahal bisa jadi perasaan ini muncul dari ketidaktahuan kita terkait kondisi pasar. Empathize dibutuhkan disini oleh calon pebisnis dengan mau mendengar dan terbuka terhadap informasi apapun dari luar dan tidak membenturkan informasi dari luar dengan keinginan sendiri. Menempatkan informasi dari luar sebagai bagian terpenting dari proses membuat sebuah bisnis.

Langkah kedua yang harus dilakukan oleh calon pebisnis adalah define. Pebisnis mensarikan informasi dari luar yang didapat menjadi beberapa hal terpenting untuk mewakili kebutuhan yang ada pada target pasar yang dituju. Caranya dengan menbandingkan informasi yang kita peroleh dengan kemampuan yang kita miliki. Kita harus memilih sesuai kemampuan untuk memudahkan langkah dalam berbisnis. Pasar yang dituju juga harus divalidasi. Jika informasi tidak valid maka kita harus mencari informasi baru dan perlu proses yang berulang. 
Ideate yaitu mengeksporasi pikiran untuk menemukan solusi (Sarooghi et al., 2019). Ide didapatkan dari hasil informasi dari dua Langkah sebelumnya. Jika asumsi sudah divalidasi dan hasilnya positif maka saatnya menentukan ide. Ide selanjutnya divalidasi ke calon pasar apakah benar ide dibutuhkan oleh pasar. Ini juga merupakan proses yang berulang.

Ide yang sudah ada dapat diwujudkan kedalam bentuk yang nyata. Manusia sebagai makhluk visual tentu harus dipuaskan dengan membuat ide menjadi sebuah produk/ jasa yang terlihat, bisa dirasakan dan bisa diuji. Prototype yang dibuat sesuai dengan konsep ide diuji Kembali, apabila belum valid maka harus diuji Kembali dengan bersedia merombak prototype menjadi prototype baru dan harus diuji kembali, ini juga merupakan proses yang berulang.

Langkah kelima adalah uji validitas produk. Kita selesaikan prototype menjadi bentuk yang sudah jadi. Para startup menyebut minimum varibel point (bentuk minimal yang sudah bisa digunakan oleh konsumen). Konsumen diminta untuk mencoba apakah prototype sudah sesuai dengan pasar. Apabila hasil validasi memberikan banyak input, prototype harus bersedia dirombak, proses juga tetap berulang. Proses bisa dari pertama sekali atau pada tahap tertentu.

Validasi prototype yang sudah berjalan sesuai rencana maka bisa dilanjutkan kepada proses implementasi. Implementasi dapat berupa produksi massal jika bentuknya produk atau pengembangan jumlah pengguna jika prototype adalah aplikasi. jika validasi tidak sesuai rencana, masih banyak kritikan, dan belum siap untuk dilanjutkan. Prototype dikembalikan lagi ke proses awal atau penyempurnaan prototype.

Langkah terakhir menyiapkan prototype menjadi produk final untuk diperkenalkan dan dipasarkan. Langkah langkah tersebut dimaksudkan untuk meminimalkan risiko pasar dan memastikan ide cocok dengan pasar yang dituju.

Akhir materi, pemateri melanjutkan diskusi singkat dan menutup dengan empat kalimat kunci :

1. Jangan jatuh cinta pada ide sendiri. Pebisnis pemula jangan berfikir sebagai seniman, membuat karya tanpa peduli karya bisa dijual atau tidak, pemilik bisnis harus berfikir pembeli adalah raja, kita membuat produk sesuai kebutuhan konsumen). Pemateri mencontohkan, jika kita memutuskan untuk membuat produk smartphone tapi ternyata pasar yang kita tuju adalah orang orang yang sudah lanjut usia, maka memberikan bermacam fitur akan sia-sia sebab kebutuhan hanya untuk menelepon.

2. Malas mengulang proses. Kegagalan pebisnis awal bukan pada kemampuan teknis tapi non teknis karena gagal menangkap kebutuhan pasar.

3. Menutup diri pada potensi perubahan ide. Ide awal dari sebuah bisnis akan berbeda dengan produk yang akan diluncurkan hal ini biasa karena bisnis berkembang pesat sesuai perkembangan zaman dan teknologi.

4. Menutup diri pada perubahan kondisi pasar. Pasar sudah berubah tapi kita kekeh bertahan maka bisnis akan gagal. Contoh blackberry sebuah produk yang besar gagal membuka diri pada kondisi pasar pada saat yang tepat.

Materi Design Thinking yang sudah disampaikan melalui ceramah dilanjut dengan sesi diskusi. Sesi diskusi dipandu dari Pusat Pengembangan Wirausaha. Sesi ini lebih kepada sharing kelompok taruna yang butuh banyak masukan mewujudkan ide dan gagasan menjadi peluang bisnis. Beberapa hasil diskusi yang bisa disimpulkan bahwa taruna belum terlalu memahami ide bisnis yang diambil, hanya melihat yang mudah dilakukan tanpa melakukan proses riset sederhana atau mencari informasi. Materi yang diberikan dan diskusi paling tidak bisa menjawab kebutuhan kelompok wirausaha taruna.

Di akhir kegiatan pendamping metode CPDT, pendamping memberikan penugasan kepada kelompok taruna. Penugasan berupa mereview Kembali ide bisnis yang ada dengan menggunakan design thinking, menyiapkan job decription masing-masing anggota kelompok wirausaha, memperdalam skill pengolahan usaha, membuat account Instagram minimal 50 follower, riset pasar sederhana oleh kelompok kewirausahaan Mekanisasi Perikanan berupa pendapat pembeli setelah mengkonsumsi gorengan yang dikeringkan menggunakan oil spinner.

Pusat Pengembangan Wirausaha Taruna membentuk group Whatsapp untuk mewadahi komuniksasi lebih intensif progam pendampingan yang dilakukan. Group diberi nama pemenang kewirausahaan untuk memacu semangat wirausaha adalah orangorang yang bermental pemenang. Gambar 2 . Group untuk optimalisasi diskusi. 


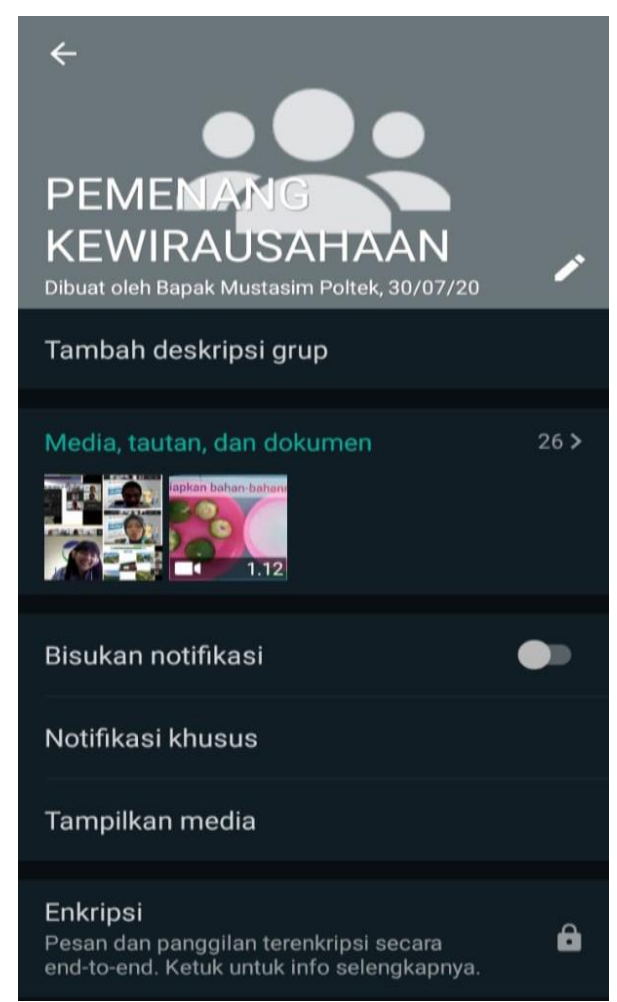

Gambar 2. Pembentukan Group Whatsapp

Pertemuan kedua berlangsung dua
minggu setelah pertemuan pertama. Pertemuan kedua ini tidak memberikan materi, pertemuan membahas dan memberikan masukan penyusunan proposal bisnis yang disusun masih tidak sesuai dengan pedoman yang diberikan serta masih terdapat kelemahan-kelemahan pada aspek aspek yang diminta seperti latar belakang, tujuan bisnis, deskripsi produk, perencanaan pemasaran bisnis, proyeksi keuangan, dan analisa risiko bisnis.

Pembahasan proposal bisnis dilakukan secara bersama untuk semua proposal bisnis kelompok kewirausahan taruna. Metode pendampingan proposal dilakukan dengan pendampingan taktis yaitu proposal yang feasible untuk diwujudkan dan pendampingan struktur Proposal sesuai dengan standar proposal bisnis (Fitriani and Ma'ruf, 2019). Proposal bisnis yang didampingi sesuai tabel 2.

Tabel 2. Proposal yang dilakukan Pendampingan

\begin{tabular}{lll}
\hline No & $\begin{array}{l}\text { Program } \\
\text { Studi }\end{array}$ & \multicolumn{1}{c}{$\begin{array}{c}\text { Judul Proposal } \\
\text { Bisnis }\end{array}$} \\
\hline 1 & Teknik & Krupuk Kulit Ikan \\
& $\begin{array}{l}\text { Penangkapan } \\
\text { Ikan }\end{array}$ & $\begin{array}{l}\text { Tuna } \\
\end{array}$ \\
\hline 2 & $\begin{array}{l}\text { Mekanisasi } \\
\text { Perikanan }\end{array}$ & $\begin{array}{l}\text { Oli Drainer Spinner } \\
\text { Machine }\end{array}$ \\
\hline 3 & Teknik & Olahan Mangrove \\
& Budidaya & \\
\hline
\end{tabular}

\section{Perikanan}

Pendamping membedah proposal bisnis selangkah demi selangkah untuk memudahkan kelompok wirausaha taruna memahami pembuatan proposal. Langkah pertama dimulai dari latar belakang. Bagian ini sangat penting dalam sebuah proposal bisnis. Kelompok taruna masih melakukan copy paste dalam latar belakang. Latar belakang bisnis harus dapat menjelaskan menjelaskan alasan melakukan kegiatan wirausaha yang akan dijalankan. Tindak lanjut latar belakang bisnis dapat ditentukan tujuan wirausaha yang akan dijalankan. Deskripsi produk merupakan hal yang penting dibuat dengan baik untuk menarik minat calon investor atau calon konsumen berinvestasi/ membeli produk yang ditawarkan. Deskripsi produk harus jelas mengambarkan bahan pembuat produk, kegunaan produk, dan proses pembuatannya. Penjelasan di deskripsi produk yang baik, benar, dan lengkap akan menjadi pertimbangan bagi konsumen untuk membeli.

Langkah selanjutnya adalah perencanaan strategi pemasaran bisnis. Strategi pemasaran bisnis ini merupakan alternatif upaya untuk menjangkau target pasar yang potensial membeli produk. Penentuan strategi pemasaran ini dapat dilakukan dengan metode SWOT. Hasil SWOT dapat menentukan strategi yang tepat untuk digunakan oleh bisnis. Implementasi strategi dapat menggunakan marketing mix konsep 7P (product, price, place, promotion, people, process, dan physical evidence). Pemasaran juga tidak terlepas dari perkembangan teknologi informasi. Bisnis harus memperhatikan ini untuk dapat bertahan dan tetap eksis di pasar. Proyeksi keuangan yang dibuat oleh kelompok kewirausahaan masih belum sesuai harapan. Kelompok dalam penentuan harga jual tidak memperhitungkan biaya tenaga kerja, Break Event Point. Kesalahan membuat proyeksi ini juga akan berimbas kepada keberlanjutan bisnis. Seraya membedah proyeksi bisnis, pendamping memberikan masukan-masukan proyeksi keuangan yang baik. Masukan dan saran ini dimintakan untuk dapat dimasukkan di dalam perbaikan proposal. Risiko merupakan peristiwa yang tidak dapat dipastikan, bila terjadi akan berdampak kepada keberlanjutan usaha (Lokobal, Sumajouw, and Sompie, 2014). Analisa risiko bisnis dibutuhkan dalam sebuah bisnis sebagai bentuk tindakan preventif untuk mengurangi dampak kerugian dari ketidakpastian yang akan mengakibatkan terganggunya keberlanjutan usaha. Tahapan yang harus dilakukan dimulai dari penetapan 
tujuan, identifikasi risiko sampai kepada analisa risiko.

Usai membedah proposal, kegiatan dilanjutkan membahas penugasan yang diberikan pada pertemuan pertama. Penugasan membuat job description sudah dilakukan dengan baik. Ketua kelompok sudah membagi masing-masing anggota dengan job description yang sesuai sehingga semua anggota memiliki pedoman kerja dan tanggung jawab terhadap peran yang diberikan. Upaya memperdalam skill pengolahan usaha juga sudah dilakukan dengan bimbingan dosen pembimbing kewirausahaan selama penugasan dua minggu.

Penugasan membuat account Instagram sudah dilakukan oleh kelompok wirausaha taruna. Pendamping meminta account yang sudah dibuat bisa memiliki 50 akun follower, namun sampai pada pengumpulan tugas account yang dibuat belum memenuhi target yang ditugaskan. Hasil penugasan dapat dilihat pada gambar 3 . Berikut :
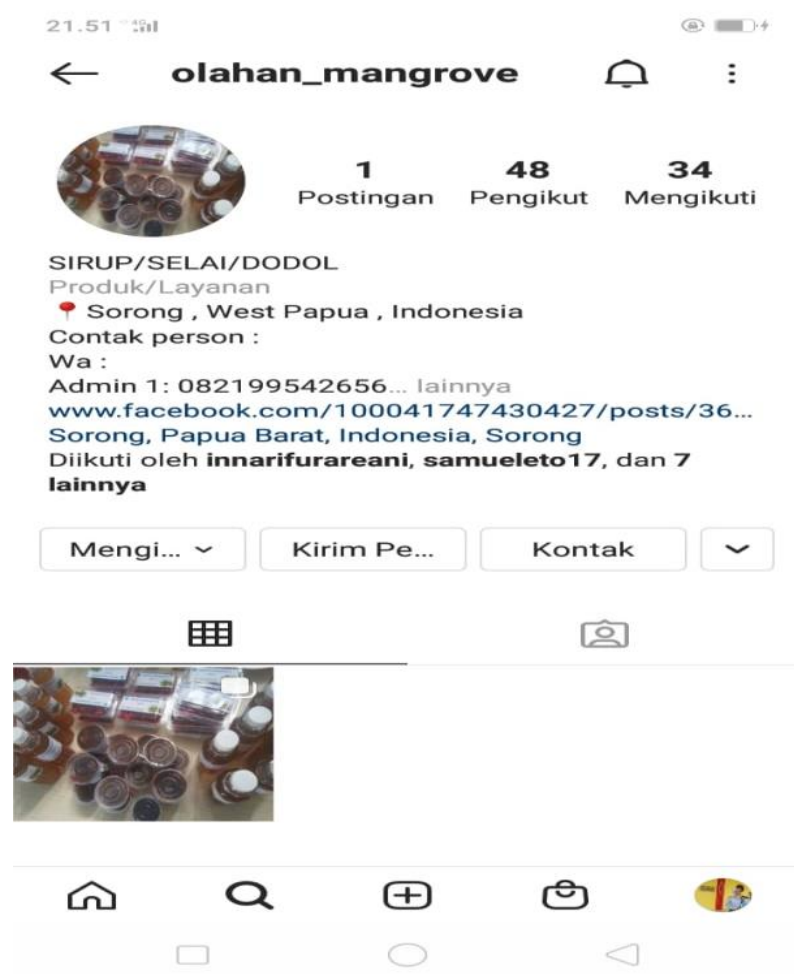

Gambar 3. Akun Instagram kelompok wirausaha taruna

Pendamping berupaya mengeksplorer dengan melakukan coaching kepada kelompok wirausaha taruna. Alur coaching secara ringkas sebagai berikut :

Coach : "Apa yang dibutuhkan untuk dapat meningkatkan follower menjadi 50?"

Coachee : "saya akan memulai follow akun teman teman saya"

Coach : "kondisi saat ini belum mencapai target, faktor apa yang mempengaruhinya?"

Coachee : "teman-teman saya belum banyak memiliki account Instagram. Saya akan memfollow orang lain".

Coach : "kapan anda akan memulainya?"

Coachee : saya akan segera memfollow akun orang lain dan berencana menfollow akun selebriti"

Coach : "adakah kiat lain untuk menambah follower?"

Coachee : saya akan sering melakukan posting-posting yang berkualitas".

Penugasan Riset sederhana berupa pendapat pembeli setelah mengkonsumsi gorengan yang dikeringkan menggunakan oil spinner drainer di wilayah Kota Sorong memperoleh hasil. Hasil survey di beberapa tempat penjual gorengan tidak menggunakan oil spinner drainer dan pelaksanaan survey dibatasi kondisi covid-19.

Kelompok krupuk tuna tidak mengikuti sesi pendampingan kedua. Ketidakikutsertaan kelompok ini dikarenakan Sebagian anggota kelompok mengikuti kegiatan observer, Sebagian lagi kondisi sinyal yang terbatas di daerah. Sesi pendampingan diganti dengan jadwal tersendiri.

Kegiatan pendampingi juga diikuti oleh kelompok kewirausahan alumni. Kelompok kewirausahaan alumni bakso kribo meminta saran kepada pendamping langkah-langkah usaha yang baik. Kelompok juga belum memiliki Pangan Industri Rumah Tangga (PIRT). Pendamping merekomendasikan alumni untuk menghubungi penyuluh perikanan yang telah berhasil mendorong Usaha Mikro, Kecil dan Menengah (UMKM) perikanan yang telah berhasil mendorong usaha binaannya memperoleh PIRT. Pendamping juga merujuk laman web untuk diakses dalam mempermudah proses pembuatan PIRT.

Pertemuan ketiga dilaksanakan 3 minggu setelah pertemuan kedua. Pertemuan disesuaikan dengan jadwal kegiatan kampus dan kalender akademik. Penyesuaian ini dilakukan untuk tidak menggangu aktivitas yang sudah terjadwal.

Pertemuan ini membahas pemasaran dan penjualan. Kelompok kewirausahaan taruna diminta untuk mempresentasikan pemasaran dan penjualan produk/jasa yang sudah dihasilkan. Kegiatan prentasi sesuai pada gambar 4 dibawah. 


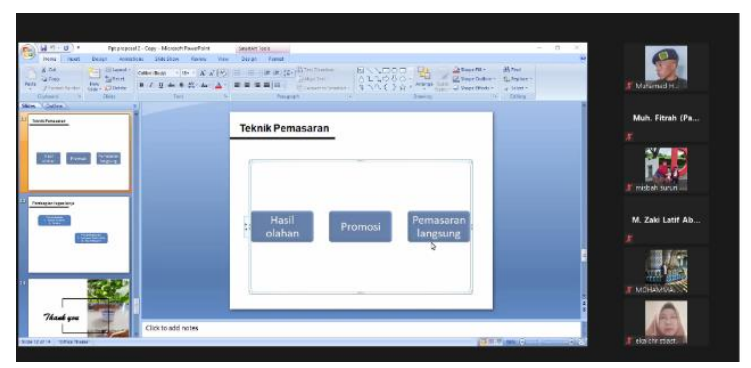

Gambar 4. Kegiatan Presentasi Pemasaran dan Penjualan

Kelompok wirausaha mangrove melakukan dua strategi pemasaran dan penjualan produk olahan mangrove. Strategi pertama yang dilakukan adalah melakukan penjualan langsung pada tempat keramaian seperti di lingkungan sekitar bandara, taman, pantai, dan Pelabuhan. Strategi kedua yang dilakukan adalah melakukan penjualan online melalui facebook, Instagram, dan whatsapp. Strategi pemasaran langsung dapat dilihat pada gambar 5 .

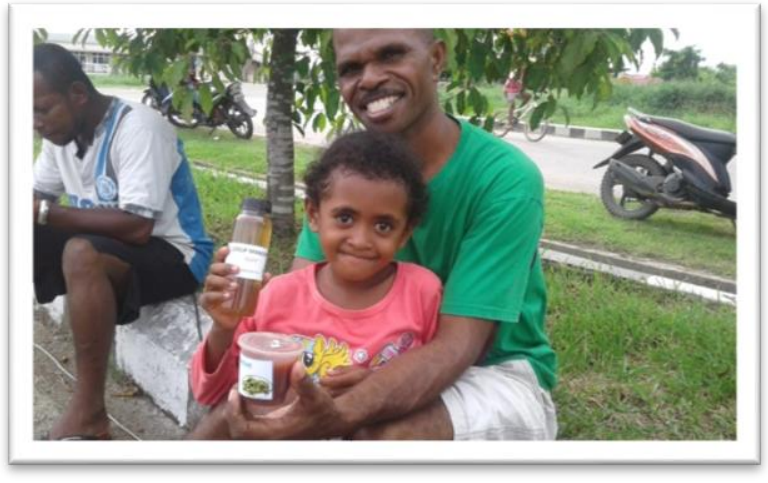

Gambar 5. Strategi Penjualan Langsung Kelompok Wirausaha

Pertemuan keempat merupakan rangkaian pertemuan terakhir pendampingan. Pertemuan ini membahas presentasi bisnis dan pelaporan. Pertemuan sekaligus membahas rencana kompetisi wirausaha nasional yang akan diikuti di Jakarta.

Sebuah laporan akan menyajikan informasi yang berharga dan mudah untuk dibaca oleh pengguna. Kelompok wirausaha diberikan pemahaman pembuatan laporan keuangan sederhana, laporan persediaan, dan laporan kegiatan sederhana. Pemahaman ini dapat menjadi bekal untuk meningkatkan performa kelompok kewirausahaan.

Pada bagian akhir juga diberikan masukan-masukan atas kekurangan melakukan presentasi bisnis. Masukan yang diberikan diantaranya tidak terkesan membaca saat presentasi bisnis dan melakukan improvisasi dalam presentasi untuk menarik perhatian.

Evaluasi dilakukan untuk melihat peningkatan softskill dari pendampingan. Evaluasi dilakukan oleh pendamping satu minggu sebelum kompetisi kewirausahaan kelautan dan perikanan nasional. Hasil dapat dilihat pada tabel

Tabel 3. Hasil Evaluasi Kelompok wirausaha

\begin{tabular}{|c|c|c|}
\hline No & Materi & Capaian \\
\hline 1 & $\begin{array}{l}\text { Proses penciptaan } \\
\text { ide kreatif }\end{array}$ & $\begin{array}{l}\text { Adanya } \\
\text { perubahan } \\
\text { kemasan } \\
\text { produk }\end{array}$ \\
\hline 2 & $\begin{array}{l}\text { Penyusunan } \\
\text { Proposal Bisnis dan } \\
\text { Prototype } \\
\text { Produk/Jasa }\end{array}$ & $\begin{array}{l}\text { Tercapai } \\
\text { peningkatan } \\
\text { kualitas } \\
\text { proposal }\end{array}$ \\
\hline 3 & $\begin{array}{ll}\text { Pemasaran dan } \\
\text { Penjualan }\end{array}$ & $\begin{array}{lr}\text { Muncul } & \text { lebih } \\
\text { dari } & \text { dua } \\
\text { strategi } & \\
\text { pemasaran }\end{array}$ \\
\hline 4 & $\begin{array}{l}\text { Presentasi Bisnis } \\
\text { dan Pelaporan }\end{array}$ & $\begin{array}{l}\text { Kemampuan } \\
\text { presentasi } \\
\text { meningkat } \\
\text { jauh lebih baik } \\
\text { dari sebelum } \\
\text { pendampingan }\end{array}$ \\
\hline
\end{tabular}

\section{SIMPULAN DAN SARAN Simpulan}

Perguruan tinggi memiliki peran dalam membentuk sosok wirausaha yang mempunyai kemampuan dan ketrampilan handal untuk mengelola sumber daya laut setelah lulus dari pendidikan. Pembentukan ini dilakukan melalui kegiatan pendampingan bagi kelompok wirausaha taruna dan alumni. Hasil kegiatan pendampingan yang dilakukan melalui Metode CPDT dan coaching dapat menumbuhkan kreativitas kelompok wirausaha, proposal yang dibuat sesuai dengan pedoman, kelompok mampu melakukan presentasi yang menarik dan efektif.

\section{Saran}

Metode CPDT dapat diterapkan pada pembelajaran mata Kuliah kewirausahaan untuk menggerakkan kelas menjadi aktif. Pengabdian masyarakat yang akan datang dapat dilakukan pelatihan kepada dosen pembimbing untuk menyamakan persepsi cara melakukan pendampingan dan pendampingan diperluas kepada alumni.

\section{UCAPAN TERIMAKASIH}

Ucapan terima kasih kami sampaikan kepada Kepala Pusat Penelitian dan Pengabdian Masyarakat atas saran dan masukan kepada kegiatan ini. Bapak Kepala Pusat Pengembangan Kewirausahaan atas 
jerih payah sehingga kegiatan ini dapat berlangsung sesuai tujuan.

\section{DAFTAR RUJUKAN}

Ananda, R., \& Amiruddin, A. (2019). Perencanaan Pembelajaran.

Budianto, A. E., Dianawati, E., \& Iswahyudi, D. (2019). Penerapan Program Pengembangan Kewirausahaan Pada Mahasiswa (Tenant) di Universitas Kanjuruhan Malang. Kumawula: Jurnal Pengabdian Kepada Masyarakat, 2(1), 93-103.

Fitriani, S., \& Ma'ruf, F. (2019). Membentuk jiwa kewirausahaan melalui pendampingan proposal bisnis. Seminar Nasional Hasil Pengabdian Kepada Masyarakat, 453-458.

Jaharuddin, J., Purnawan, I., Mujiastuti, R., Muthmainnah, R. N., \& Prasetyawati, M. (2019). Strategi Melahirkan Mahasiswa Pengusaha Pemula (Studi Kasus Mahasiswa Universitas Muhammadiyah Jakarta). Jurnal Kewirausahaan Dan Bisnis, 24(13), 25-37.

Jerusalem, M. A. (2011). Peningkatan keterampilan bisnis mahasiswa dengan teknik coaching. Prosiding Pendidikan Teknik Boga Busana, 6(1).

Kadar, A. (2015). Pengelolaan kemaritiman menuju Indonesia sebagai poros maritim dunia. Jurnal Keamanan Nasional, 1(3), 427-442.

Kusuma, R., \& Erlita. (2012). Pengaruh pendidikan kesehatan dengan metode ceramah plus diskusi dan tugas (CPDT) terhadap sikap remaja putri di SMPN 29 Surabaya. Jurnal IImu Kesehatan, 1(1).

Lasabuda, R. (2013). Pembangunan wilayah pesisir dan lautan dalam perspektif Negara Kepulauan Republik Indonesia. Jurnal IImiah Platax, 1(2), 92-101.

Lokobal, A., Sumajouw, M., \& Sompie, B. (2014). Manajemen Risiko Pada Perusahaan Jasa Pelaksana Konstruksi Di Propinsi Papua (Study Kasus Di Kabupaten Sarmi). Jurnal Ilmiah Media Engineering, 4(2), 109118.

Meinel, C., \& Von Thienen, J. (2016). Design thinking. Informatik-Spektrum, 39(4), 310-314.

Sarooghi, H., Sunny, S., Hornsby, J., \& Fernhaber, S. (2019). Design Thinking and Entrepreneurship Education: Where Are We, and What Are the Possibilities? Journal of Small Business Management, 57(S1), 78-93. https://doi.org/10.1111/jsbm.12541
Sasvia, H. (2019). Penegakan Hukum Perikanan di Wilayah Laut Indonesia. Lex Scientia Law Review, 3(2), 227234.

Suprapto, H. A. (2019). Pengaruh Pembuatan Proposal Rencana Bisnis (Business Plan) Terhadap Kemampuan Berwirausaha di SMK Bhakti Husada. JURNAL ILMIAH WAHANA PENDIDIKAN, 5(2), 19-23.

Suranto, S., Setiawan, E., \& Sujalwo, S. (2018). Menumbuhkan Semangat Wirausaha Mahasiswa Berbasis Potensi. IENACO (Industrial Engineering National Conference) 6 2018.

Yuliawan, T. P. (2011). Coaching Psychology: Sebuah Pengantar. Buletin Psikologi, 19(2). 